\title{
Promising Strain of Acinetobacter from Soil for Utilization of Gluconic Acid Production
}

\section{Topraktaki Gelecek Vaadeden Acinetobacter Suşunun Glukonik Asit Üretiminde Kullanımı}

\author{
Research Article

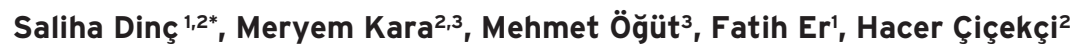 \\ 'Selcuk University Cumra School of Applied Sciences, Konya-Turkey. \\ ${ }^{2}$ Selcuk Uni. Advanced Technology Research and Application Center, Konya-Turkey. \\ ${ }^{3}$ Selcuk University Cumra Vocational High School, Konya-Turkey.
}

\section{A B S TR AC T}

\begin{abstract}
Cluconic acid, a food additive, is used in many foods to control acidity or binds metals such as calcium, $J$ iron. Acinetobacter sp. WR326, newly isolated from soil possesses high phosphate solubilizing activity and do not require pyrroloquinoline quinone (PQQ) for glucose dehydrogenase (GDH) activity as cofactor In this study the gluconic acid production potential of this bacterium was investigated. Firstly, Acinetobacter sp. WR326 was incubated in tricalcium phosphate medium (TCP) with varying glucose concentrations (100, 250, $500 \mathrm{mM}$ ), at a temperature of $30^{\circ} \mathrm{C}$ for 5 days (120 hours). The highest gluconic acid yield (59\%) was found at a glucose concentration of $100 \mathrm{mM}$. Then three different levels of gluconic acid addition to the medium (50, 100, $200 \mathrm{mM}$ ) were tested. When Acinetobacter sp. WR326 strain was cultivated with a $100 \mathrm{mM}$ glucose and $100 \mathrm{mM}$ gluconic acid the yield increased to $95.27 \%$. In any trials 2 -keto D-gluconic acid, causes problems in processing and purification of the gluconic acid, was not detected in the medium. As a conclusion, Acinetobacter sp. WR326 may be considered novel potential bacterial strain for gluconic acid production.
\end{abstract}

\section{Key Words}

Acinetobacter sp. WR32, gluconic acid, fermentation, phosphate solubilizing bacteria, biotechnology.

\section{öz}

Clukonik asit asitliği kontrol etmek veya kalsiyum, demir gibi metalleri bağlamak için gıdalarda kullanılan bir

$\mathcal{J}$ katkı maddesidir. Topraktan yeni izole edilen Acinetobacter sp. WR326, yüksek fosfat çözme aktivitesine sahiptir ve glukoz dehidrojenaz $(G D H)$ aktivitesi için pyrroloquinoline quinone (PQQ) kofaktörüne gereksinim duymamaktadır. Bu çalışmada bu bakterinin glukonik asit üretme potansiyeli araştırılmıştır. İlk önce, Acinetobacter sp. WR326 farklı glukoz derişimlerde (100, 250, $500 \mathrm{mM}) 30^{\circ} \mathrm{C}$ sıcaklıkta 5 gün boyunca (120 saat) trikalsiyum fosfat (TCP) besiyerinde inkübe edilmiştir. En yüksek glukonik asit verimi (\%59) 100 mM'lık glukoz derişimi içeren kültürde bulunmuştur. Sonra besiyerine glukonik asit ilavesi üç farklı derişimde (50, 100, 200 mM) araştırılmıştır. Acinetobacter sp. WR326 suşu 100 mM glukoz ve 100 mM glukonik asit ilavesinde kültüre alındığında verim \%95.27 oranına yükselmiştir. Hiçbir koşulda glukonik asidin işlenmesi ve saflaştırılmasında problemlere neden olan 2-keto D-glukonik asit tespit edilmemiştir. Sonuç olarak, Acinetobacter sp. WR326 suşunun glukonik asit üretiminde yeni potansiyel bakteri suşu olarak kullanılabileceği düşünülmektedir.

\section{Anahtar Kelimeler}

Acinetobacter sp. WR32, glukonik asit, fermentasyon, fosfat çözücü bakteriler, biyoteknoloji.

Article History: Received: Mar 25, 2017; Revised: May 15, 2017; Accepted: Aug 12, 2017; Available Online: Dec 25, 2017. DOI: $10.15671 /$ HJBC.2018.203

Correspondence to: S. Dinç, Selcuk University Advanced Technology Research and Application, Konya, Turkey. 


\section{INTRODUCTION}

Iuconic acid and its salts (sodium and calci7 um) are widely used in food, pharmaceutical, feed, cement, textile and chemical industries $[1,2]$. The use of gluconic acid (E 574) as a food additive has been permitted by the European Parliament and Council Directive No. 95/2/EC. Additionally, sodium gluconate is being used in food industry as a substance GRAS (generally recognized as safe) status. The demand for gluconic acid used in different industries is raising day by day $[3,4,5]$. It is widely accepted that gluconic acid will be one of the top-30 most produced substances from biomass resources in the future [6].

Gluconic acid can be produced by chemical oxidation, electrolysis and fermentation $[2,7]$. However, microbial fermentation is the method of choice while it is cheaper and no undesired reactions occur $[1,7]$. Gluconic acid is produced by the fungi genera Aspergillus, Penicillum, Gliocladium, and Endomycopsis, yeasts such as Aureobasidium and by other microorganisms like Acetobacter and Gluconobacter, and Pseudomonas [7]. However, it is mainly produced by strains of Aspergillus niger [4,8]. New approaches in studies dealing with gluconic acid production include (i) isolation of new microorganisms, (ii) optimization of the fermentation conditions and (iii) utilization of cheap carbohydrate sources in fermentation $[6,9,10]$.

Dissolved phosphorus is an important factor in plant growth. Phosphate solubilizing bacteria (PSB) convert insoluble phosphate into soluble forms in the soil by releasing organic acids $[11,13]$. PSB mostly secret gluconic acid produced by direct oxidation of glucose via glucose dehydrogenase (GDH) for the dissolution of hardly soluble phosphorus [1214]. Although the phosphate solubilizing microorganisms were treated as phosphate solubilizer, they were almost never considered as gluconic acid producer in earlier studies. Ogut et al $[12,15]$ isolated Acinetobacter sp. WR326 from soil (Tokat, Turkey) and found out that the Acinetobacter sp. WR326 has a high phosphate solubilizing capacity. High phosphate solubilizing capacity is attributed to production of gluconic acid by GDH. For the activation of $G D H$, pyrroloquinoline quinone (PQQ) as a cofactor is required. Many bacteria such as Acinetobacter sp. Iwoffii and some E.coli strains synthesize apoqui- noprotein (apoGDH), not PQQ $[16,17]$. As a result, for the oxidation of glucose and phosphate solubilization either the PQQ externally be provided or must be produced in the cell. Ogut et al [12] had shown in their study that Acinetobacter sp. WR326 is PQQindependent phosphate solubilizing microorganism. Considering the high phosphate solubilizing capacity and $P Q Q$ independent property of these newly isolated bacteria, in this study, we tested the gluconic acid production potential at varying glucose and gluconic acid concentrations.

\section{MATERIAL and METHODS}

\section{Microorganisms and Medium}

A $24 \mathrm{~h}$ culture of each Acinetobacter sp. WR326 (Genbank accession number: HM438960) was used. For the cultivation, TCP medium was used and the composition of the medium was shown in Table 1 [12]. Different levels of glucose $(100,250,500 \mathrm{mM})$ and gluconic acid $(50,100,200 \mathrm{mM})$ were used in the medium. Glucose, TCP, yeast extract, $\mathrm{MgSO}_{4} \cdot 7 \mathrm{H}_{2} \mathrm{O}, \mathrm{CaCl}_{2}$, $\mathrm{Ca}_{3}\left(\mathrm{PO}_{4}\right)_{2}$ were supplied from Merck, Germany. A volume of $50 \mu \mathrm{L}$ culture was transferred to a $250 \mathrm{~mL}$ Erlenmeyer flasks containing $50 \mathrm{~mL}$ TCP medium. The microorganisms were cultivated in a shaking incubator (Heidolph D-91126 Schwobach, Germany) set to $30^{\circ} \mathrm{C}$ temperature and $150 \mathrm{rpm}$ in an aerobic condition. The samples for the HPLC (High performance liquid chromatography) analysis were taken from the 24,72 and 120 hours old cultures. They were stored at (-) $18^{\circ} \mathrm{C}$ until analysis.

\section{Experimental Design}

At the first stage Acinetobacter sp. WR326 was incubated in tricalcium phosphate medium (TCP) with 100,250 and $500 \mathrm{mM}$ glucose concentrations at a temperature of $30^{\circ} \mathrm{C}$ for 5 days (120 hours). At the end of incubations the gluconic acid yields were determined and the highest one was recorded to be used at the second stage of experiment.

At the second stage three different levels $(50,100,200 \mathrm{mM})$ of gluconic acid were added to medium together with above mentioned glucose concentration and incubated at the same conditions above. Then gluconic acid yields were recorded. 


\section{Determination of Gluconic Acid and 2-Keto d-Dluconic Acid}

The gluconic acid and 2-keto D-gluconic acid levels were quantitatively analyzed by HPLC (Shimadzu, Japan) using Shodex RS Pak DE-613 (ID $6.0 \mathrm{~mm} x$ $\mathrm{L} 150 \mathrm{~mm}$ ) column. Elution was performed with an isocratic solvent $\mathrm{HClO}_{4}(2 \mathrm{mM})$ with a flow rate of $0.5 \mathrm{~mL} \mathrm{~min}^{-1}$ at $200 \mathrm{~nm}$ wavelength. The column temperature was set at $30^{\circ} \mathrm{C}$. The standards of gluconic acid (Merck, Germany) and 2-Keto D- gluconic acid (Sigma Aldrich, U.S.A) were prepared in water. The elution times of the peaks of the samples were compared with the elution time of the standard peak. The limit of detection (LOD) values for 2-keto D-gluconic acid and D-gluconic acid were $3.25 \times 10^{-9} \mathrm{mM}$ and $3.85 \times 10^{-9} \mathrm{mM}$, respectively. The samples were centrifuged at 11.000 rpm for 5 minutes (Nüve NF 800, Turkey) after defrosting. The supernatant was diluted to 1:15 and analyzed by HPLC after filtering through 0.45 $\mu \mathrm{m}$ filters.

\section{Statistical Analysis}

Triplicate measurements of gluconic acid and 2-keto gluconic acid values were statistically evaluated by analysis of variance (ANOVA) procedure using SPSS statistical software ver. 14.0 (SPSS Inc., Chicago, IL). The differences among the means were compared using Duncan's multiple comparison [18].

\section{RESULTS and DISCUSSION}

The medium given in Table 1, was used for cultivation of Acinetobacter sp. WR326. Since Acinetobacter sp. WR326 is PQQindependent phosphatesolubilizing microorganism we didn't add PQQ. Acinetobacter sp. WR326 produced gluconic acid in all experiments (Table 2). In this study, whether Acinetobactersp. WR326 produces 2-keto $D$-gluconic acid or not was also investigated (Figure 1). Because the keto acids cause problems in processing and purification of the gluconic acid [10]. Acinetobacter sp. did not produce 2-keto D-gluconic acid in this study. Hen$c e$, it seems to be an advantage that the bacteria used in this study do not produce 2-keto gluconic acid.
Table 1. Composition of tricalcium phosphate medium.

\begin{tabular}{lcc}
\hline Medium (for $1 \mathrm{~L})$ & $\begin{array}{c}\text { Stage I: Effect } \\
\text { of glucose } \\
\text { concentration }\end{array}$ & $\begin{array}{c}\text { Stage II: Effect } \\
\text { of gluconic acid } \\
\text { concentration }\end{array}$ \\
\hline Yeast Extract $(\mathrm{g})$ & 0.5 & 0.5 \\
\hline $\mathrm{MgSO}_{4} \cdot 7 \mathrm{H}_{2} \mathrm{O}(\mathrm{g})$ & 0.25 & 0.25 \\
\hline $\mathrm{CaCl}_{2}(\mathrm{~g})$ & 0.10 & 0.10 \\
\hline $\mathrm{Ca}_{3}\left(\mathrm{PO}_{4}\right)_{2}(\mathrm{~g})$ & 5 & 5 \\
\hline $\mathrm{Glucose}_{(\mathrm{mM})}$ & $100,250,500$ & 0.1 \\
\hline $\begin{array}{l}\text { Gluconic Acid } \\
(\mathrm{mM})\end{array}$ & - & $50,100,200$ \\
\hline
\end{tabular}

The amounts of gluconic acid in the cultures and the production yields are shown in Table 2 . The gluconic acid production yields were calculated by dividing the average gluconic acid amount by the amount of glucose added to the medium and multiplying the result by 100 . Different glucose concentrations affected the gluconic acid production potential of the Acinetobacter sp. WR326 strain. The gluconic acid levels increased with longer incubation times at all glucose concentration except at 500 $\mathrm{mM}$ glucose (Table 2). The glucose concentration of $500 \mathrm{mM}$ was not suitable for the Acinetobacter sp. WR326 strain. Similar results were found in a study where the fungus Aspergillus niger was cultivated at varying glucose concentrations and varying fermentation conditions [1]. In this study it was found that the gluconic acid decreased when the glucose concentration exceeded $120 \mathrm{~g} \mathrm{~L}^{-1}$. In our study the highest yield of gluconic acid was determined in the medium containing $100 \mathrm{mM}$ glucose. So we used a glucose concentration of $100 \mathrm{mM}$ thereinafter. When the 120 hours incubation period is taken into consideration, the highest gluconic acid level (21.10 $\mathrm{g} \mathrm{mL}^{-1}$ ) were determined in the medium containing $250 \mathrm{mM}$ glucose (Table 2). However, the production efficiency at that concentration was low.

As the addition of the gluconic acid to the medium probably solubilized the tricalcium phosphate to release phosphorus ions, which are readily usable in bacterial energy metabolism [12-14]. The effects of gluconic acid addition into the medium were also investigated.

In the calculation of yield, the effect of gluconic acid addition was considered. Different gluconic acid addition levels to the medium $(50 \mathrm{mM}$, 
Table 2. The amount and yield of gluconic acid.

\begin{tabular}{|c|c|c|c|c|c|}
\hline & \multirow{2}{*}{$\begin{array}{l}\text { Glucose Concentration } \\
(\mathrm{mM})\end{array}$} & \multirow{2}{*}{$\begin{array}{c}\text { Incubation Period } \\
\text { (hour) }\end{array}$} & \multicolumn{3}{|c|}{ Gluconic Acid Amount (g. $\left.\mathrm{L}^{-1}\right)$} \\
\hline & & & \multicolumn{2}{|c|}{ Mean $\pm S D^{*}$} & Yield\% \\
\hline & \multirow{3}{*}{100} & 24 & \multicolumn{2}{|c|}{$7.07 \pm 0.018^{f}$} & 39.26 \\
\hline & & 72 & \multicolumn{2}{|c|}{$10.40 \pm 0.007^{d}$} & 57.70 \\
\hline & & 120 & \multicolumn{2}{|c|}{$10.63 \pm 0.009^{c}$} & 59.00 \\
\hline & \multirow{3}{*}{250} & 24 & \multicolumn{2}{|c|}{$7.80 \pm 0.009 e$} & 17.32 \\
\hline \multirow[t]{7}{*}{ Stage 1} & & 72 & \multicolumn{2}{|c|}{$12.49 \pm 0.006^{b}$} & 27.73 \\
\hline & & 120 & \multicolumn{2}{|c|}{$21.10 \pm 0.036^{a}$} & 46.85 \\
\hline & \multirow{3}{*}{500} & 24 & \multicolumn{2}{|c|}{$6.12 \pm 0.008^{g}$} & 6.80 \\
\hline & & 72 & \multicolumn{2}{|c|}{$6.10 \pm 0.011^{g}$} & 6.77 \\
\hline & & 120 & \multicolumn{2}{|c|}{$5.92 \pm 0.003^{h}$} & 6.57 \\
\hline & \multirow{2}{*}{$\begin{array}{l}\text { Glucose Concentration } \\
\qquad(\mathrm{mM})\end{array}$} & \multirow{2}{*}{$\begin{array}{l}\text { Gluconic Acid } \\
\text { Concentration } \\
\text { (mM) }\end{array}$} & \multirow{2}{*}{$\begin{array}{l}\text { Incubation } \\
\text { Period } \\
\text { (hour) } \\
\text { Mean } \pm \text { SD* }\end{array}$} & \multicolumn{2}{|c|}{ Gluconic Acid Amount (g. $\left.\mathrm{L}^{-1}\right)$} \\
\hline & & & & Yield (\%) & \\
\hline \multirow{9}{*}{ Stage 2} & \multirow{3}{*}{100} & \multirow{3}{*}{$\begin{array}{c}50 \\
72 \\
120\end{array}$} & 24 & $5.49 \pm 0.047$ & 30.45 \\
\hline & & & $9.26 \pm 0.030^{g}$ & 51.42 & \\
\hline & & & $11.79 \pm 0.028^{d}$ & 65.44 & \\
\hline & \multirow{3}{*}{100} & \multirow{3}{*}{$\begin{array}{c}100 \\
72 \\
120\end{array}$} & 24 & $8.17 \pm 0.024^{h}$ & 45.33 \\
\hline & & & $13.70 \pm 0.068^{c}$ & 76.05 & \\
\hline & & & $17.16 \pm 0.031^{a}$ & 95.27 & \\
\hline & \multirow[t]{3}{*}{100} & 200 & 24 & $9.33 \pm 0.155^{f}$ & 51.57 \\
\hline & & & 72 & $10.65 \pm 0.018^{e}$ & 59.10 \\
\hline & & & 120 & $16.67 \pm 0.055 b$ & 92.53 \\
\hline
\end{tabular}

\footnotetext{
* Means followed by the same letter within each column are not significantly different and values are means \pm standard deviations of measurements of three measurements ( $p<0.05)$.
}

$100 \mathrm{mM}$ and $200 \mathrm{mM}$ ) influenced the production positively. The yield of culture media without gluconic acid was 59\%. However, following $100 \mathrm{mM}$ gluconic acid addition to culture media the yield increased to $95.27 \%$ (Table 2). The determined yield value is the same with the theoretical value determined using Aspergillus niger [7].

\section{CONCLUSION}

Acinetobacter sp. WR326 bacteria resulted in the highest yield of gluconic acid production at $100 \mathrm{mM}$ of glucose and $100 \mathrm{mM}$ of gluconic acid concentrations. This newly isolated and PQQ independent bacterium may be considered a novel potential gluconic acid production source according to our findings. The PQQ independency of Acinetobacter sp. WR326 may be assumed as a benefit in terms of economy during the large scale production of gluconic acid. Currently, fungi genera seem the potential producer of gluconic acid in the microbial fermentation route. This strain of Acinetobacter isolated from soil may be an alternative source for microbial fermentation route. 2 -keto D-gluconic acid was not detected in the medium. This may another advantage as the 
A

2-Keto D-Gluconic Acid D-Gluconic Acid

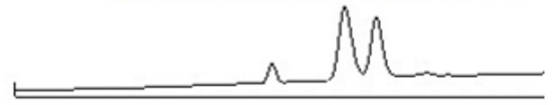

B

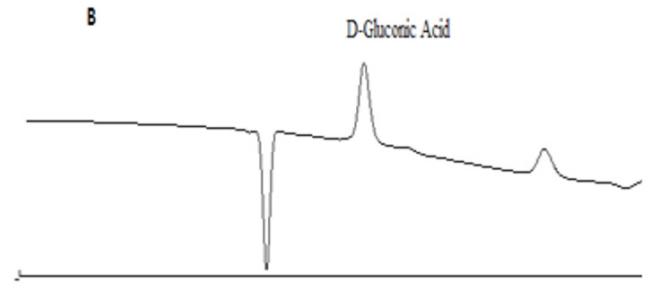

Figure 1. A: Chromatogram of D-gluconic acid; 2-Keto D-gluconic acid standards. B:Chromatogram of culture by Acinebacter sp. WR326 at glucose concentration of 100 mM. Column Shodex RSpak DE-613 (6.0 mm I.D. x 150 mm). UV-200 nm. Mobil Phase: $2 \mathrm{mM} \mathrm{HClO} 4$ a.q., flow rate: 0.5 $\mathrm{mL} / \mathrm{min}$. Column oven: $30^{\circ} \mathrm{C}$.

keto acids may cause problems in the processing and purification steps of the gluconic acid. Based on increasing demand for gluconic acid, investigation of alternative cultivation conditions are necessary to optimize the feasible gluconic acid production process.

\section{ACKNOWLEDGMENT}

This work was supported by Selçuk University No: 13401094.

\section{References}

1. O.V. Singh, K.R. Jain, R.P. Singh, Gluconic acid production under varying fermentation conditions by Aspergillus niger, J. Chem. Technol. Biotechnol., 78 (2003) 208-212.

2. S. Anastassiadis, H.J. Rehm, Continuous gluconic acid production by Aureobasidium pullulans with and without biomass retention, Electron. J. Biotechnol. (2006) 915102006.

3. H.A. El-Enshasy, Production of gluconic acid by free and immobilized cells of recombinant Aspergillus niger in batch culture, Egypt. J. Biotechnol., 13 (2003) 187-201.

4. O.V. Singh, B.M.J. Pereira, R.P. Singh, Isolation and characterization of a potent fungal strain Aspergillus niger ORS-4 for gluconic acid production, J. Sci. Ind. Res., 58 (1999) 594-600.
5. S.A. Ahmed, S.S. Farag, A.I. Hassan, W.H. Botros, Production of gluconic acid by using some irradiated microorganisms, J. Radiat. Res. Appl. Sci., 8 (2015) 374-380.

6. C. Dowdells, R.L. Jones, M. Mattey, M. Bencina, M. Legisa, D.M. Mousdale, Gluconic acid production by Aspergillus terreus, Lett. Appl. Microbiol., 51 (2010) 252-257.

7. S. Ramachandran, P. Fontanille, A. Pandey, C. Larroche, Gluconic Acid, Properties, Applications and Microbial Production, Food Technol. Biotechnol., 44 (2006) 185-195.

8. A. Sharma, V. Vivekanand, P.R. Singh, Solid-state fermentation for gluconic acid production from sugarcane molasses by Aspergillus niger ARNU4 employing tea waste as the novel solid support, Bioresour. Technol., 99 (2008) 3444-3450.

9. O.V. Singh, R.P. Singh, Bioconversion of grape must into modulated gluconic acid production by Aspergillus niger ORS-4.410, J. Appl. Microbiol., 100 (2006) 1114-1122.

10. S. Anastassiadis, A. Aivasidis, C. Wandrey, Continuous gluconic acid production by isolated yeast-like mould strains of Aureobasidium pullulans, Appl. Microbiol. Biotechnol., 61 (2003) 110-117

11. M. Stella, M.S. Halimi, Gluconic acid production by bacteria to liberate phosphorus from insoluble phosphate complexes, J. Trop. Agric. Food Sci., 43 (2015) 41-53.

12. M. Öğüt, F. Er, N. Kandemir, Phosphate solubilization potentials of soil Acinetobacter strains, Biol. Fertil. Soils, 46 (2010) 707-715.

13. T.F. Lin, H.I. Huang, F.T. Shen, C.C. Young, The protons of gluconic acid are the major factor responsible for the dissolution of tricalcium phosphate by Burkholderia cepacia CC-AI74, Bioresour. Technol., 97 (2006) 957-960.

14. P. Tallapragada, U. Seshachala, Phosphatesolubilizing microbes and their occurrence in the rhizospheres of Piper betel in Karnataka, India, Turk. J. Biol., 36 (2012) 25-35.

15. M. Öğüt, F. Er, G. Neumann, Increased proton extrusion of wheat roots by inoculation with phosphorus solubilizing microorganism, Plant Soil, 339 (2011) 285-297.

16. R.W.J. Hommes, P.W. Postma, O.M. Neijssel, D.W. Tempest, P. Dokter, J.A. Duine evidence of a quinoprotein glucose dehydrogenase apoenzyme in several strains of Escherichia coli, FEMS Microbiol. Lett., 24 (1984) 329-333.

17. M.A. Van Kleef, J.A. Duine, Factors relevant in bacterial pyrroloquinoline quinine production, Appl. Environ. Microbiol., 55 (1989) 1209-1213.

18. O. Düzgüneş, T. Kesici, O. Kavuncu, F. Gürbüz, Araştırma ve Deneme Metodları (Istatistiksel Metodları-II), Ankara Üniv. Zir. Fak. Yay., (1987) 1021, Ankara. 